\title{
THE ROLES OF BHAYANGKARA OF TRUSTEES OF SECURITY AND PUBLIC ORDER (BHABINKAMTIBMAS) OF THE POLICE OF REPUBLIC OF INDONESIA (POLRI) IN IMPLEMENTATION OF RESTORATIVE JUSTICE AGAINST CRIMINAL OF PRESECUTION IN THE LAW OF THE NORTH BENGKULU POLICE
}

\author{
By: \\ Yosril Radiansyah, Antory Royan Adyan, Hamzah Hatrik
}

\begin{abstract}
This study raises issues related to the roles of Bhabinkamtibmas and the constraints of Bhabinkamtibmas in implementing restorative justice against criminal acts of persecution in the North Bengkulu Police. This study aims to find out and analyze what the roles and constraints of Bhabinkamtibmas in implementing the process of restorative justice against criminal acts are. This research is an empirical legal research type from the facts that exist in a society, legal entity or government agency. The results of this study indicate that the existence of Bhabinkamtibmas has helped many Police institutions especially North Bengkulu Resort Police starting from the early detection of criminal acts (pre-emptive functions), the process of preventing criminal acts (preventive functions) and the process of problem solving and law enforcement (repressive functions) one of its role is as a mediator and facilitator in the process of restorative justice. The constraints or obstacles of Bhabinkamtibmas in carrying out their roles from the internal of the National Police and the personnel of Bhabinkamtibmas itself are related to knowledge, skills and ethics as well as external constraints such as the lack of a legal culture or response from the public and the absence of positive laws governing. The results of this study suggest that it needs legal reforms that accommodate the process of restorative justice in order to improve the legal culture and effectiveness of criminal law enforcement in Indonesia.
\end{abstract}

Keywords: The roles and obstacles of Bhabinkamtibmas Polri in the implementation of restorative justice. 


\section{A. INTRODUCTION}

\section{Research Background}

The National Police of the Republic of Indonesia, abbreviated as Polri as one of the law enforcement apparatuses, is one of the institutions or state institutions in Indonesia that carries out the duties of protecting and serving the public, maintaining security and ordering, and enforcing the law based on law number 02 of 2002 concerning Police of the Republic of Indonesia. It is required to be able to carry out its tasks in a professional, transparent and accountable manner. ${ }^{1}$

Within the structure of the Police Institution, there are the main functions of the police that operate in 3 (three) aspects, namely Preemptive, Preventive and Repressive. The Binmas function which includes Bhabinkamtibmas is the bearer of the main duties of the police in order to protect and serve the public, maintain security and order as well as prevent criminal acts and also carry out law enforcement in accordance with the main tasks of the National Police in general.

${ }^{1}$ Article 13 of Law No 02 of 2002 about Main Tasks of Polri.
The number of cases that are resolved peacefully and not proceed to the judicial process by Bhabinkamtibmas officers requires a Bhabinkamtibmas to have competence in solving problems that contain philosophical meaning as well as restorative justice for problems that arise in the jurisdiction of their duties. Through peace mediation mediated by Bhabinkamtibmas personnel together with local village officials from the results of the settlement of the criminal act, peace agreement is reached with a settlement carried out by consensus at the village level so that the criminal case is not proceeded to the investigation stage by the National Police investigator. ${ }^{2}$

\section{Identification of Problems}

1. What is the roles of the National Police of Bhabinkamtibmas in the implementation of restorative justice against criminal acts of persecution in the jurisdiction of North Bengkulu Resort Police?

${ }^{2}$ Based on data from the North Bengkulu Police Resort of Binmas unit regarding the case resolution report by Bhabinkamtibmas semester 1 (one) in 2016. 
2. What are the obstacles of the National Police Bhabinkamtibmas in implementing restorative justice against criminal acts of persecution that exist in the jurisdiction of North Bengkulu Resort Police?

\section{B. RESEARCH METHODOLOGY}

This type of research includes empirical legal research, which is a legal research method that functions to see the law in the real sense and examine how law works in the community, while the nature of this research is descriptive. A descriptive study, intended to provide as much detailed data as possible about humans, conditions or other symptoms. ${ }^{3}$

Data was obtained by conducting interviews with respondents in accordance with a list of questions that have been prepared previously and developed at the time of the interview by limiting questions in accordance with aspects of the problem under study, with respondents as follows:

a. Chief of North Bengkulu Police
${ }^{3}$ Soerjono Soekanto, 1986, Metode Penelitian Hukum, UI Press, Jakarta, Page. 10. b. Chief of Binmas Unit of North Bengkulu Police

c. Member of

Bhabinkamtibmas of North

Bengkulu Police

d. Police chief of Rural type in North Bengkulu regency (Ketahun police station)

e. Member of the Police Sector of Bhabinkamtibmas of Ketahun

f. Police chief of Prarural type in the district of North Bengkulu (Air Besi Police Sector)

g. Member of

Bhabinkamtibmas of Air Besi Police Station

h. Village officials / Village head

i. Perpetrators of criminal acts of persecution.

j. Victims

Secondary data was obtained through library research (library research), which relates to the object of this study in accordance with the title of the thesis. This data is used to support primary data. Secondary data consists of: ${ }^{4}$

\footnotetext{
${ }^{4}$ https://ngobrolinhuku m.wordpress.com/2014/08/09/da ta-sekunder-dalam-penelitianhukum-normatif/ assessed on August $15^{\text {th }}, 2016$
} 
a. Primary Legal Material.

Legal materials in the form of the 1945 Constitution of the Republic of Indonesia, Law No.02 of 2002 concerning the National Police of the Republic of Indonesia, Regulation of the National Police Chief 03/2001 concerning community policing, and Decree of the Police Chief Number: $\quad$ Kep/618/VII/2014, concerning Buku Pintar (Smart Book) of Bhabinkamtibmas.

\section{RESULTS AND DISCUSSION}

\section{The Role of Bhabinkamtibmas in} the Implementation of Restorative Justice against Criminal Acts of Persecution in the North Bengkulu Police.

Bhabinkamtibmas is an
abbreviation of Bhayangkara of
Trustees of Public Security and
Order which is a member of the
Indonesian National Police (Polri) in
charge of fostering public security
and order (Kamtibmas).
The existence of Bhabinkamtibmas personnel in each village has greatly contributed positively to the implementation of the national police's duties in protecting and serving the community, in enforcing the law and in maintaining kamtibnas in the community. If there are social problems and kamtibmas problems in the village or sub-district that are their task area, such as the occurrence of criminal acts of persecution, the presence of Bhabinkamtibmas personnel can greatly assist the North Bengkulu Police institution starting from the early detection process of a criminal act (carrying the preemptive function), the process of preventing the occurrence criminal acts (carrying out preventive functions) and preventing access from criminal acts, problem solving processes and law enforcement processes (carrying out repressive functions). ${ }^{5}$

The Principal Task of Bhabinkamtibmas regulated in article 27 of Perkap No. 3 of 2015 is to conduct community development, early detection and mediation/negotiation in order to create conducive conditions in the village / sub-district. In carrying out its main tasks.

Bhabinkamtibmas carries out the following activities: House to house visits, conducting and assisting problem solving, organizing and

${ }^{5}$ Results of interviews with Chief of North Bengkulu Police, AKBP Andhika Vishnu, S.IK 
securing community activities, receiving information about criminal acts, providing guidance to the community or groups in relation to Kamtibmas issues and police services. ${ }^{6}$

The role of Bhabinkamtibmas in the case of persecution in the village can be resolved peacefully in the village (restorative justice) and some cannot in the village (cannot be restorative justice), a rare step taken by Bhabinkantibnas is to become a mediator of consensus agreement by presenting both parties litigation parties, heads and village officials, BPD, Community leaders, religion to solve the problem of persecution. Furthermore, Bhabinkamtibmas will make a report on the resolution of problems in the village in the Bhabinkamtibmas report. Meanwhile, if the problem is not resolved peacefully (restorative justice) then the problem will be brought to the Police office to be continued and followed up by the Criminal Investigation Unit Investigator in the Sectoral Police through the investigation process and the investigation process in

${ }^{6}$ Results of interviews with Chief of Binmas Unit of North Bengkulu Police AKP. Muzakir accordance with the provisions of applicable criminal procedure law. ${ }^{7}$

Based on the theory of criminal law policy according to Prof. Sudarto argued that criminal policy is also an integral part of social policy. Social policy can be interpreted as a rational effort to achieve social welfare (social welfare policy) and at the same time include community protection (social defense policy). In short it can be said that the ultimate goal or main objective of criminal policy is "the protection of society to achieve prosperity. Rational efforts to control or overcome crime (criminal politics) use two means, namely:

a. Criminal Policy with Penal Facilities is the repetition of crime using criminal law.

b. Criminal Policy with NonPenal Facilities. This policy only includes the use of social facilities to improve certain social conditions, but indirectly affect efforts to prevent crime. ${ }^{8}$

\footnotetext{
${ }^{7}$ Results of interviews with Police chief of Prarural type in Air Besi police station, IPDA. Rahmat, S.H.

${ }^{8}$ Barda Nawawi Arief. 2002,
} Bunga Rampai Kebijakan Hukum Pidana. PT Citra Aditya Bakti, Bandung. pg.77-78 
The role played by the National Police of Bhabinkamtibmas personnel in carrying out their duties can be defined as one form of criminal law policy taken and carried out by the National Police of Bhabinkamtibmas personnel by using the Police discretion inherent in the Police personnel.

\section{The Constraints and Obstacles} of the National Police of Bhabinkamtibmas in the implementation of restorative justice against criminal acts of persecution that exist in the jurisdiction of North Bengkulu Resort Police.

The constraints and obstacles in the implementation of the tasks of the special bhabinkamtibmas related to the implementation of restorative justice against criminal acts internal obstacles and obstacles:

a Lack of human resources personnel bhabinkamtibmas both in terms of quantity and quality.

b. In terms of quantity, the number of Bhabinkamtibmas personnel is still very minimal and unbalanced between the number of Bhabinkamtibmas personnel and the number of villages in the North Bengkulu Police Precinct. c. In quality, the skill, knowledge and behavior (attitude) of bhabinkamtibmas personnel are also not optimal, still weak in mastering the police sciences, techniques and tactics in serving as well as the behavior of bhabinkamtibmas personnel who have not reflected themselves as protective protector.

While external obstacles and obstacles are as follows:

a. The public's lack of trust in the police as a protector of community guards and servants.

b. Lack of cooperation with stake holders in the village in terms of law enforcement and in terms of maintaining harkamtibmas.

c. The absence of specific rules that serve as guidelines in the resolution of cases or the resolution of cases in restorative justice, resulting in personnel bhabinkamtibmas become afraid of acting and blamed legally and blamed by the leadership.

d. Low level of public education and the lack of good culture of the community in daily life.

Based on the theory of law enforcement according to Soerjono Soekanto conceptually the meaning of "Law Enforcement lies in the activity of harmonizing the relationships of 
values that are spelled out in the rules that are solid and manifest and the attitude of action as a series of translation of final stage values, to create, preserve, and maintain peace of association of life ". 9

When viewed further, law enforcement is not merely implementing the law, although in reality it is often stated in Indonesia (Law Enforcement). Basically, law enforcement lies in the factors that influence it, which has a neutral meaning so that the positive and negative impacts lies in the contents of these factors, as follows:

a. The legal factor itself, which in this paper will be limited to the Act only.

b. Factors of Law enforcement, namely those who apply the law.

c. Factors of facilities that support law enforcement.

d. Community factors, namely the environment in which the law applies or is applied.

e. Cultural factors, namely as the results of works, inventions, and tastes based on human initiative in the association of life. ${ }^{10}$

\footnotetext{
${ }^{9}$ Soerjono Soekanto, FaktorFaktor Yang Mempengaruhi Penegakan Hukum, Rajawali Pers, Jakarta, 2012,
} Pg. 5

\footnotetext{
${ }^{10}$ Soerjono Soekanto, Op. Cit,
}

The existence of the Bhabinkamtibmas Personnel in carrying out their roles and duties is one of the factors that can influence law enforcement in Indonesia.

\section{CONCLUSIONS AND}

\section{SUGGESTIONS}

\section{Conclusions}

The existence of Bhabinkamtibmas personnel can greatly assist the National Police institutions, starting from the early detection of criminal acts (carrying out pre-emptive functions), the process of preventing criminal acts (carrying out preventive functions) and preventing access from criminal acts, the process of solving problems and the process of law enforcement (carrying out functions repressive). In carrying out its duties, Bhabinkamtibmas personnel are in accordance with Perkap No. 3 of 2015 concerning community policing, the main task of Bhabinkamtibmas is to conduct community development, early detection and mediation/negotiation in order to create conducive conditions in the village/sub-district.

Bhabinkamtibmas 
personnel in carrying out their role as Police personnel have a Police discretion that can be interpreted as a criminal law policy with their own consideration and pay attention to the dynamics that develop, among others, provide assistance and become a mediator or facilitator in mediating problem solving by cooperating and empowering all elements in the village / sub-district (village chiefs and apparatus, religious leaders, community leaders, traditional leaders) by involving perpetrators, victims, their families and other parties involved in resolving conflicts in the community through restorative justice channels, providing information and reporting to top unity, both the police and the police related to the handling and settlement of criminal acts that occur, assisting the process of investigation and investigation of criminal acts if they are still being processed through the provisions of the passed criminal law, maintaining the stability of Kamtibmas in the village related to access and consequences add to the occurrence of criminal acts, and looking for the root of the problems that exist and finding the best solution for the benefit of the community in the village/subdistrict.

The constraints and obstacles of the National Police of Bhabinkamtibmas in the implementation of restorative justice against criminal acts of persecution that exist in the jurisdiction of North Bengkulu Police are divided into two, internal and external constraints, including:

\section{a. Internal}

1) Lack of human resources personnel of Bhabinkamtibmas both in terms of quantity and quality.

a) In terms of quantity, the number of

Bhabinkamtibmas

personnel is still very minimal and is not balanced between the number of

\section{Bhabinkamtibmas}

personnel and the number of villages in the North

Bengkulu 
Regional Police area.

b) In quality, ability, knowledge and behavior (attitude) personnel bhabinkamtibmas are also not yet optimal, the weak in mastering legal and police sciences, techniques and tactics in the task as well as the behavior of personnel bhabinkamtibmas that have not been reflecting themselves as protector and servant of the people.

2) There is still a lack of facilities and infrastructure needed to support the implementation of tasks in the village.

3) The absence of special rules both from the criminal law rules and regulations from the internal Police that can serve as a positive law that can be used in the resolution of cases or the settlement of cases by restorative justice, resulting in Bhabinkamtibmas personnel becoming doubtful, afraid of acting and afraid of being blamed by the law and blamed by the leadership.

\section{b. External}

1) Public mistrust of the police as a protector of community guards and servants, a sense of antipathy and a negative response to the presence of police personnel in the field so that it requires a special approach to the community.

2) A sense of lack of trust and dissatisfaction of the community with the restorative justice law enforcement carried out, and feel more satisfied if a criminal case has to be resolved through a trial process in court.

3) Lack of cooperation with stake holders in the village in terms of law enforcement and in terms of protecting public health and safety.

4) The low level of public education and the lack of good culture of the community in daily life, which is still often 
evidenced by the vigilante action.

5) Customary law is not yet running and the role of customary instruments in the village is not yet optimal in helping to resolve problems traditionally in the village.

6) The absence of a positive legal rule from criminal law that can be used as a procedural law that accommodates the process of restorative justice can be used as a handle in the settlement of cases or the settlement of cases in restorative justice.

\section{Suggestions}

From the description of the discussion and conclusion, suggestions can be made as follows:

1. Criminal law is based on ultimum remidium, therefore it is recommended that in handling criminal cases by law enforcement officers (Police, Prosecutors, Judges) have procedures that become guidelines when it is possible to the application of restorative justice apply.

2. In addition to increasing the role of

\section{Bhabinkamtibmas}

personnel in implementing restorative justice against criminal acts in the village, special training needs to be provided special training for Bhabinkamtibmas personnel, so that they can improve their skills, knowledge and attitude in carrying out their duties to become professional, modern and reliable.

3. There needs to be a change in the criminal procedure code in Indonesia. Criminal Procedure Code is to accommodate the procedural law for resolving crimes committed through restorative justice. With the existence of procedural law that accommodates restorative justice, it is expected to be a positive legal reference for law enforcement officers (police, prosecutors, judges, and legal advisors) in carrying out 
their duties to realize justice, legal certainty, and provide legal benefits for the people of Indonesia.

\section{BIBLIOGRAPHY}

Books

Ade saptomo. 2013. Budaya hukum dan kearifan lokal sebuah perspektif perbandingan. Jakarta : Fakultas hukum universitas pancasila.

Badra Nawawi Arief. 2010.Masalah penegakan hukum dan kebijakan hukum pidana dalam penanggulangan kejahatan. Semarang : Kencana.

2011.Reformasi sistem peradilan (sistem penegakan hukum).Semarang : Badan penerbit Universitas Diponegoro.

2014.Mediasi penal penyelesaian perkara pidana diluar pengadilan.Semarang : Pustaka magister.

2014. Bunga rampai kebijakan hukum pidana : perkembangan penyusunan konsep Kuhp baru. Semarang : Kencana.

Herlambang, 2013, Tindak Pidana Penerimaan Hasil Korupsi, Bogor : PT. Penerbit IPB Press.

Lukman Santoso AZ. 2016. Pengantar Ilmu Hukum, sejarah, pengertian, konsep hukum, aliran hukum dan penafsiran hukum. Malang : Setara press.

Otong Rosyadi. 2012. Studi politik hukum suatu optik ilmu hukum. Padang : Thafa media.

Ronny Hanitijo Soemitro, 1990, Metode Penelitian Hukum ,Ghalia Indonesia, Jakarta.
Soerjono Soekanto, 2012, faktor faktor yang mempengaruhi penegakan hukum, Jakarta, Raga grafindo persada.

Soerjono Soekanto, 1986, Metode Penelitian Hukum, Jakarta : UI Press. Wirjono Prodjodikoro, 2012, TindakTindak Pidana Tertentu Di Indonesia,, PT. Refika Aditama, Bandung.

Journal

jurnal ilmiah ilmu hukum Bengkoelen justice volume 5 nomor 2, November 2015.

Regulation

Undang-Undang Dasar Republik Indonesia Tahun 1945.

Undang-Undang Republik Indonesia Nomor 2 Tahun 2002 Tentang Kepolisian Negara Republik Indonesia.

Keputusan Kepala Kepolisian Negara Republik Indonesia Nomor: Kep/618/VII/2014 tentang Buku Pintar Bhabinkamtibmas.

Peraturan Kepala Kepolisian Negara Republik Indonesia Nomor: 03 tahun 2015 tentang Pemolisian masyarakat.

Website

http://konsulatlaros.blogspot.co.id/2012/10/ pengertianimplementasimenurut.html di akses tanggal 15 agustus 2016.

http://bungalegal.blogspot.co.id/2010/02/teoritujuan-hukum.html di akses tanggal 15 agustus 2016

https://ngobrolinhukum.wordpress.com/201 4/08/09/data-sekunder- 
dalampenelitian-hukum-normatif/ di akses tanggal 15 agustus 2016

https://idtesis.com/metode-penelitianhukum-empiris-dan-normatif/ di akses tanggal 15 agustus 2016

http://eprints.umk.ac.id/2679/3/Makalah_S L_OB_23_Juni_2013_OYE.pdf yang diakses pada tanggal 17 agustus 2016

https://www.scribd.com/doc/76443160/Imp lementasi-Restorative-JusticeOlehPenyidik-Polri diakses tanggal 17 agustus 2016

http://repo.unsrat.ac.id/365/1/PENERAPA N_MEDIASI_OLEH_LEMBAGA KEPOLISIAN_REPUBLIK_INDON ESIA_DALAM_PENANGGANAN_ TINDAK_PIDANA_SEBA.pdf yang diakses tanggal 17 agustus 2016. 
